Book Chapter in Derluyn, II, Mels, C., Parmentier W., and Vandenhole W. (eds.) (2012) Re-Member:

rehabilitation, reintegration and reconciliation for war-affected children, volume 11 Series on Transitional

Justice. Cambridge/Antwerp/Portland: Intersentia Publishers.

\title{
Support to the education and livelihoods of war-affected children and youth in northern Uganda
}

\author{
Ann Lorschiedter, Femke Bannink-Mbazzi
}

This article focuses on a practitioner's approach to support for children and youth who are affected by the war in northern Uganda that lasted from 1986 to 2006, which has usually been portrayed as a barbaric war or "one of the worst humanitarian crises in the world", according to the then Head of UN Humanitarian Affairs Jan Egeland in 2003.

The authors critically review essential aspects of this war, aiming to focus mainly on children and youth in northern Uganda. In doing so, they elaborate on some key issues of the phenomenon of "child soldiers", then widen the focus to include war-affected children and youth in order to overcome a limitation of programming. They argue that singling out former abductees or "ex-child soldiers" from other vulnerable groups and individuals is problematic.

The work of AVSI, an international non-governmental organisation operating in northern Uganda since 1984, is described as an example of supporting vulnerable children and youth through education and gaining a livelihood.

\section{The war in northern Uganda}

At the beginning of the last century, 80 to 90 percent of war casualties worldwide were military personnel and 10 to 20 percent were civilian and unarmed. By the end of the century, these figures were reversed. ${ }^{2}$ Today, in northern Uganda and elsewhere, armed conflicts and civil wars have blurred the distinction between "combatants" and "civilians", and "civilian" itself is a diffuse and broad category of non-combatants who are living in the midst of conflict. Frontlines are not easily defined and non-combatants are often targets of harassment and deadly violence.

In northern Uganda, more than two million people were displaced from their homes as a result of the conflict between the northern Ugandan Lord's Resistance Army (LRA), led by rebel leader Joseph Kony, and the Government of Uganda, headed by General Yoweri Museveni. ${ }^{3}$ From 1986 to 2006, the rhythm of the war in northern Uganda has been an uneven one, with sometimes long periods of lull in the fighting and rather peaceful times during which people could lead an almost "normal" life, working in their gardens and travelling rather safely on the roads. In 2005, however, nearly $90 \%$ of the population in Gulu, Kitgum and Pader Districts, those most affected by violence, had relocated into camps for internally displaced people. The IDP Camps have often been described as a scenario of extremely poor, even inhuman living conditions, dominated by military restrictions and impoverishment, where all aspects of life were severely affected, resulting in generally high vulnerability and dependency on support from outside. ${ }^{4}$ In the predisplacement setting, every family lived in its own compound, and in the evenings family members gathered by the fireplace to share supper and for traditional teaching. The displacement characterised by overcrowded camps and lack of security resulted in destruction of the social fabric, with people living in a "state of fear and anxiety". 5 Youth could hardly access educational facilities and had almost no means of generating an income, which led to self-destructive practices such as drinking alcohol, unprotected sex and early marriage.

Although the war in northern Uganda has often been perceived as a local, northern Ugandan conflict and in many cases as a "primitive" or "barbaric" war, it has instead been part of a complex regional war in which the neighbouring countries Sudan and Congo were involved and which was - and still is - threatening security beyond northern Uganda. At present (autumn 2009), the LRA remains active after having shifted to southern Sudan, north-eastern Congo and the Central African Republic, causing tens of thousands to flee their homes in the Democratic Republic of Congo and leaving hundreds dead, ${ }^{6}$ and it is as yet uncertain whether the future will eventually bring lasting peace to the people in the region. ${ }^{7}$

\footnotetext{
${ }^{1}$ http://www.un.org/News/Press/docs/2003/afr750.doc.htm [accessed 30 July 2009].

${ }^{2}$ T. Allen and J. SEATON: 'Introduction', In AlLEN, T. and J. SEATON (eds), The Media of Conflict: War reporting and representations of ethnic violence, London and New York, 1999, at 1-8; M. KALDOR, 'The structure of conflict', in L. WOHLGEMUT, S. GIBSON, S. KLASEN, and E. ROTHSCHILD (eds), Common security and civil society in Africa, Uppsala, 1999, 126; C. NORDSTROM, 'The backyard front', in C. NORDSTROM and J.A. MARTIN (eds), The paths to domination, resistance and terror, Berkeley, 1999, 155, 170.

${ }^{3}$ InTERNATIONAL CRISIS GROUP, Northern Uganda: Understanding and Solving the Conflict. Nairobi, Brussels, 2004 http://www.unhcr.org/refworld/docid/407e70554.html [accessed 12 July 2009].

${ }^{4}$ C.O. AKUMU, I. AMONY and G. OTIM, Suffering in silence: A study of sexual and gender based violence (SGBV) in Pabbo Camp, Gulu District, Northern Uganda, 2005, http://www.reliefweb.int/library/documents/2005/unicef-uga-15jun.pdf [accessed 19 July 2009]; J.N. CoRBIN, 'Returning home: Resettlement experiences of formerly abducted children in northern Uganda', (2008) Disasters (Online Early Articles), at 316-335; E. STITES,

D. MAZURANA, and K. KARLSON, Movement on the margins: Livelihoods and Security in Kitgum District, Northern Uganda. Boston, 2006.

${ }^{5}$ Retired Bishop Baker Ochola quoted in IRIN NEWS: http://www.irinnews.org/InDepthMain.aspx?InDepthId=23\&ReportId=65810

${ }^{6}$ BEYOND JuBA, The Uganda Conflict Timeline, 2009. http://www.beyondjuba.org/conflict timeline.php [accessed 17 August 2009]

${ }^{7}$ UNITED NATIONS SECURITY COUNCIL, Northern Uganda/LRA Historical Chronology, 2009.

http://www.securitycouncilreport.org/site/c.glKWLeMTIsG/b.2880391/ [accessed 5 August 2009]; M. SCHOMERUS, Perilous border: Sudanese communities affected by conflict on the Sudan-Uganda border, Conciliation Resources, London, 2007.
} 
Book Chapter in Derluyn, II, Mels, C., Parmentier W., and Vandenhole W. (eds.) (2012) Re-Member: rehabilitation, reintegration and reconciliation for war-affected children, volume 11 Series on Transitional Justice. Cambridge/Antwerp/Portland: Intersentia Publishers.

\section{1 "Child soldiers" in the LRA}

\subsubsection{Conscription of minors into the LRA and DDR}

In most cases, and especially since the 1990s when the LRA experienced a decrease in local support, children and youth in the LRA were abducted and did not join the rebel army as volunteers as was the case in other wars in Africa and elsewhere. Such volunteers have various motives in joining armed forces, most often linked to the war itself, poverty, education, employment and/or family. ${ }^{8}$ Their reasons for joining armed forces voluntarily distinguish this group from abductees and must first be identified and addressed before they can be supported in their process of reintegration. ${ }^{9}$ Unlike in other countries where children and youth were included in large-scale DDR (Demobilisation, Disarmament and Reintegration) programmes, past programming in northern Uganda focused mainly on the reintegration aspect.

\subsubsection{Statistics on abduction}

According to a report from the enough! project in February 2008, the insurgency in northern Uganda "has resulted in arguably the highest number of child abductions in the world"; ${ }^{10}$ however, the report did not indicate specific figures. Some estimates of the number of LRA abductions appear to be higher than previously suggested, and the whereabouts of most of those abductees who have not yet returned from captivity remains unknown. By triangulating data from different sources on the number of former abductees, the Berkeley Report estimates that the LRA had abducted 24,000 to 38,000 children and 28,000 to 37,000 adults as of April 2006. The authors of the study, however, observed gaps in the data collection and insufficient information management in reception centres, and a lack of information on returnees who never passed through such a centre. ${ }^{11}$ The Survey of War Affected Youth estimates that 66,000 children and youth were abducted, that more than 10,000 people were killed and that many thousands more mutilated during the conflict. ${ }^{12}$ An exact number of children, youth and adults who have been abducted over the 20 -year period will most likely never be available, owing to the lack of reliable statistics.

The age of those who were abducted by the rebels, as well as the length of time they spent in captivity, varied considerably. The involvement of children in the war has been "sometimes exaggerated": research shows that between 1997 and 2001, less than one third of those abducted were children. ${ }^{13}$ Also, not children but youths older than 12 years were usually a main target for the LRA's abductions, on average staying in captivity for more than one year. Among those who were abducted for more than two weeks, 25 percent reported having been forced to kill civilians or soldiers. 80 percent of the abductees eventually managed to escape from the LRA, with the remaining number released by the LRA or captured by the UPDF. ${ }^{14}$

\subsubsection{Mystification of "child soldiers"}

Ugandan and international media usually portrayed the conflict in northern Uganda as the barbaric war of one fanatical religious rebel leader with no clear political agenda, massacring people from his own "tribe". Often, media reports and research echoed this limited view and mystification also in relation to one category of its victims, namely children and youth who were forcefully abducted by the LRA rebels.

Not only but also regarding northern Uganda, "child soldiers" are often described as children heavily armed with a machine gun or a machete and turned into reckless little monsters and killing machines. Such portrayals, along with the most sensational interviews of children who had been abducted, forced to kill and commit other atrocities, are contributing to a myth of child soldiering in which the children and youth are seen as victims and perpetrators at the same time, as "time bombs" and "emotional cripples" who are totally disconnected from their family and community, deeply traumatised due to rape, forced marriage and childbirth, killings and lootings, and unable ever to live a normal

http://www.c-r.org/our-work/uganda/documents/Perilous-Border.pdf [accessed 3 August 2009].

${ }^{8}$ D.M. Rosen, Armies of the Young: Child Soldiers in War and Terrorism, Piscataway, 2005.

${ }^{9}$ R. BRETT, 'Adolescents volunteering for armed forces or armed groups', (2003) 85 Affaires courantes et commentaries - Current issues and comments 852,859 .

${ }^{10}$ J. Prendergast and L. Rogoff, 'R2P, the ICC and Stopping Atrocities in the Real World', (2008) 13 Enough Strategy paper, 2. www.responsibilitytoprotect.org/files/ENOUGH\%20Report.pdf [accessed 2 July 2009].

${ }^{11}$ P.N. Pham, P. VINCK, and E. STOVER, Abducted: The Lord's Resistance Army and Forced Conscription in Northern Uganda. Berkeley-Tulane Initiative on Vulnerable Populations. Human Rights Center, University of California, Berkeley and Payson Center for International Development, Tulane University, 2007.

http://www2.reliefweb.int/rw/RWB.NSF/retrieveattachments?openagent\&shortid=EVOD-76JJG5\&file=Full Report.pdf [accessed 5 July 2009].

12 J. ANnAN, C. BLATTMAN and R. HoRTON, The State of Youth and Youth Protection in Northern Uganda: Findings from the Survey of War Affected Youth. Kampala, UNICEF Uganda, 2006.

${ }^{13}$ T. ALLEN and M. SCHOMERUS, A Hard Homecoming: lessons Learnt From the Reception Centre Process on Effective Interventions for "Former Abductees" in Northern Uganda. An Independent Study. Washington, DC., 2006, vi.

http://pdf.usaid.gov/pdf_docs/PNADI241.pdf [accessed 8 August 2009]

${ }^{14}$ C. BlatTMANN and J. ANNAN, 'Child combatants in northern Uganda: Reintegration myths and realities', in R. MUGGAH (ed), Security and Post-

Conflict Reconstruction: Dealing with Fighters in the Aftermath of War, Routledge, 2008, at 103-126. 
Book Chapter in Derluyn, II, Mels, C., Parmentier W., and Vandenhole W. (eds.) (2012) Re-Member: rehabilitation, reintegration and reconciliation for war-affected children, volume 11 Series on Transitional Justice. Cambridge/Antwerp/Portland: Intersentia Publishers.

life again but instead posing an ongoing security threat in their communities even after the war - they are seen as the "lost children". Although thousands of the children and youth abducted by the LRA have indeed undergone many of the events listed above, local realities often show that many of them have a strong resilience which helps them to redefine their lives after captivity and to find a place in their society. ${ }^{15}$

\subsubsection{The quantification of trauma}

"Trauma" is a widely used term for describing the impact of the war on the population in northern Uganda, especially in relation to former abductees. Symptoms of post-traumatic stress disorder (PTSD) among former abductees in northern Uganda have been investigated in several studies, for example in order to associate them with openness to reconciliation and feelings of revenge, using the Child Posttraumatic Stress Disorder Reaction Index and indicating a PTSD score. ${ }^{16}$ Other research on PTSD was carried out by asking children to recall atrocities and horrible events. ${ }^{17}$ Most of such studies undertaken on PTSD have shown high prevalence rates of symptoms of PTSD and depression among the returnees. $^{18}$

On academic grounds, discussions have been held as to whether it is ethically right to carry out research on "child soldiers" with a focus on quantifying trauma through diagnosis of PTSD. Critics do not question the existence of trauma but raise concerns about a pathologisation and stigmatisation by imposing "Western" categories, and limiting the conceptualisation of the support that may be required, especially when such research is not deeply embedded in the social, economic, cultural and political realities of the informants. ${ }^{19}$

\subsubsection{The reintegration of former "child soldiers" in the context of northern Uganda}

A large proportion of the existing research on the reintegration of returnees in northern Uganda is written within a framework of human rights, child protection, advocacy, peace and human development, often drawing on interviews with returnees and/or others close to them (family members, social workers, local leaders, teachers etc.). ${ }^{20}$ Other studies have a focus on mental health - in which often special emphasis is put on the PTSD ${ }^{21}$ or on the relevance of counselling in particular and psychosocial support in general - and some refer to reintegration from a local standpoint, often backed up by Acholi traditional and cultural aspects of healing.

Emphasis is also put on gender-based aspects of reintegration, putting in the spotlight the specific situation of girls and young women as "sex slaves" or forced "wives" of rebels or rebel commanders, highlighting an additional hardship of the "child mothers", girls or young women who gave birth in the "bush". These "child mothers" and their "children born in captivity" have increasingly been targets of special attention, with programmes specifically tailored for supporting them. ${ }^{22}$ Concerns about ethical sensitivity in conducting research with female returnees have been raised, ${ }^{23}$ and it is also suggested that discussions about these young women were "bedevilled with misconceptions". ${ }^{24}$

Media reports are increasingly to be found on the homepages of most of the larger newspapers, journals and television channels dealing with reintegration. Still, new publications on the phenomenon of abduction and on the reintegration of returnees in northern Uganda continue to be released and research projects to be designed, both for academic and programmatic purposes.

\footnotetext{
${ }^{15}$ C. Blattmann and J. AnNan, 'Child combatants in northern Uganda: Reintegration myths and realities', in R. MUGGAH (ed), Security and PostConflict Reconstruction: Dealing with Fighters in the Aftermath of War, Routledge, 2008, at 103-126.

${ }^{16}$ C.P. BAYER, F. KLASEN and H. ADAM, 'Association of Trauma and PTSD Symptoms With Openness to Reconciliation and Feelings of Revenge Among Former Ugandan and Congolese Child Soldiers', (2007) The Journal of the American Medical Association, 298 , at 555-559. http://jama.ama-assn.org/cgi/reprint/298/5/555 [accessed 17 August 2009]; F. GLÖCKNER, PTSD and Collective Identity in Former Ugandan Child Soldiers. University of Konstanz, 2007. http://nbn-resolving.de/urn:nbn:de:bsz:352-opus-33085 [accessed 30 July 2009 ].

${ }^{17}$ I. Derluyn, E. BroekAerT, G. SchUYTEN and E. DE TEMMERMAN, 'Post-traumatic stress in former Ugandan child soldiers', (2004) The Lancet 363, at 861-863. www.essex.ac.uk/armedcon/story_id/000178.pdf [accessed 15 June 2009].

${ }^{18}$ P.N. PHAM, P. VINCK and E. STOVER, 'Returning home: forced conscription, reintegration, and mental health status of former abductees of the Lord's Resistance Army in northern Uganda', (2009) 9 BMC Psychiatry, 23. http://www.pubmedcentral.nih.gov/picrender.fcgi?artid=2693494\&blobtype=pdf [accessed 18 July 2009].

${ }^{19}$ S. MCKAY and M.G. WESSELS, 'Post-traumatic stress in former Ugandan child soldiers', (2004) The Lancet $363,1646$.

${ }^{20}$ M.G. WESSELS, The Recruitment and Use of Girls in Armed Forces and Groups in Angola: Implications for Ethic Research and Reintegration, Pittsburgh, 2007, 2.

${ }^{21}$. Koesler, S. Wöhrmann, C., Zwissler, B., Pfeiffer, A., Ertl, V., Kissler, J. (2010) Does remembering cause forgetting in chronically stressed people? A Study of Ugandan Civil War Refugees With and Without PTSD Journal of Psychology, 218, 2: 71-79.

${ }^{22}$ E. MBENGUE and I. DESIREE, Effective reintegration of female child soldiers: reality or rhetoric? Case study of Northern Uganda, Pretoria, 2007. repository.up.ac.za/dspace/bitstream/.../mbengue\%20eleke id_1.pdf [accessed 2 July 2009]; K. CARLSON and D. MAZURANA, Forced marriage within the Lord's Resistance Army, Uganda, Medford, 2008.

${ }^{23}$ M.G. WESSELS, The Recruitment and Use of Girls in Armed Forces and Groups in Angola: Implications for Ethic Research and Reintegration, Pittsburgh, 2007, 20.

${ }^{24}$ T. AlLEN and M. SCHOMERUS, A Hard Homecoming: lessons Learnt From the Reception Centre Process on Effective Interventions for "Former Abductees" in Northern Uganda. An Independent Study. Washington, DC., 2006, vi. http://pdf.usaid.gov/pdf_docs/PNADI241.pdf [accessed 8 August 2009]
} 
Book Chapter in Derluyn, II, Mels, C., Parmentier W., and Vandenhole W. (eds.) (2012) Re-Member: rehabilitation, reintegration and reconciliation for war-affected children, volume 11 Series on Transitional Justice. Cambridge/Antwerp/Portland: Intersentia Publishers.

At the same time, there is a growing need to consider vulnerable youth, and not only children, in Acholiland when designing interventions targeting peace and reconciliation in northern Uganda in general, and successful reintegration in particular. $^{25}$

\subsection{Efforts to establish peace in northern Uganda}

In 2000, the Ugandan Parliament passed a comprehensive Amnesty Act "for Ugandans involved in acts of a war-like nature in various parts of the country". The Amnesty Act has been successful in providing "a way out" for those who were able to leave the LRA and be referred to a reception centre - the majority are former abductees - but the capacity of the Amnesty Commission to implement not only the reintegration of returnees but also reconciliation and justice at the local level was limited. ${ }^{26}$

While there has been no official end to the conflict yet, the majority of the displaced population in northern Uganda has started to move out of the IDP camps (in the Acholi sub-region, the original camp population at the end of 2005 was estimated to be 1,110,140 people, of whom in September 200917 percent remained in an IDP camp, while 17 percent had moved to a transit site and $74 \%$ had gone to their "villages of origin"). ${ }^{27}$ The situation in the neighbouring countries, however, is less calm, with the LRA still being active and at times causing massive havoc.

\section{Supporting war-affected children and youth through education and gaining a livelihood}

\subsection{Vulnerability in the return and resettlement setting}

In order to support youth in the process of return, specifically to improve their self-reliance and coping mechanisms, educational institutions need to be re-established and self-reliance can be promoted by skills training and income generating activities. With more than half of Uganda's population under the age of 15, education and economic skills are of paramount importance to the country's future.

Despite Uganda's introduction of a Universal Primary Education (UPE) programme in 1997 which waived school fees for primary students, education levels remain low; of the more than 2 million UPE pioneer students in 1997 less than 100,000 had continued through to completion of the senior level in 2008. Only eight percent of Ugandan males and six percent of females have completed a primary-level education, and less than one percent have completed a secondary level education. ${ }^{28}$

The war in northern Uganda, resulting in a generally increased vulnerability, has adversely impacted on access to education, the quality of education and the possibilities of pursuing economic activities in IDP Camps for youth. Despite the efforts of donors, humanitarian agencies, religious and cultural institutions and the Government, key educational indicators remain below the national averages in most of the conflict-affected districts with few exceptions, and certainly below the internationally recommended standards. The expansion in enrolment has not been matched by supply in terms of teacher recruitment and provision of facilities. Generally, the school infrastructure is relatively better in IDP camps compared to areas of origin as many were destroyed during the conflict. Literacy and numeracy rates in northern Uganda are only 54 percent, while 23 percent of children in northern districts aged 7 to 18 years reported having never been to school, attendance is irregular, and retention and completion rates are low, especially for girls. The situation for secondary school-aged children and youth is even worse. ${ }^{29}$

\footnotetext{
${ }^{25}$ J. AnNAN, C. BlattMan and R. HoRTON, The State of Youth and Youth Protection in Northern Uganda: Findings from the Survey of War Affected Youth. Kampala, UNICEF Uganda, 2006.; WOMEN's COMMISSION FOR REFUGEE WOMEN AND CHILDREN, Listening to Youth: The Experiences of Young People in Northern Uganda. Contribution to Machel 10-Year Strategic Review. New York, 2007.

http://www.unhcr.org/refworld/docid/48aa83150.html [accessed 1 August 2009]; E. BAINES, E. STOVER and M. WIERDA, War-Affected Children and Youth in Northern Uganda: Toward a Brighter Future. An Assessment Report, Chicago, 2007. http://www.macfound.org/atf/cf/\% 7BB0386CE38B29-4162-8098-E466FB856794\%7D/UGANDA REPORT.PDF [accessed 22 July 2009]; J. ANNAN, C. BLATTMAN, K. CARLSON and D.

MAZURANA, The State of Female Youth and in Northern Uganda: Findings from the Survey of War Affected Youth, Phase II. Kampala, UNICEF Uganda, 2008.; WOMEN's COMMISSION FOR REFUGEE WOMEN AND CHILDREN, Youth and Sustainable Livelihoods: Linking Vocational Training Programs to Market Opportunities in Northern Uganda, Colombia University, 2008. www.womenscommission.org/pdf/ug ysl rep.pdf [accessed 5 July 2009]; F. BANNINK-MBAZZI and A. LORSCHIEDTER, 'Psychosocial support to vulnerable youth in vocational schools in northern Uganda', (2009) 7 Intervention 2, at 130-137.

${ }^{26}$ T. ALLEN and M. SCHOMERUS, A Hard Homecoming: lessons Learnt From the Reception Centre Process on Effective Interventions for "Former Abductees" in Northern Uganda. An Independent Study. Washington, DC., 2006, vii. http://pdf.usaid.gov/pdf_docs/PNADI241.pdf [accessed 8 August 2009]

${ }^{27}$ UNOCHA, Update on IDP movement, September 2009, IASC Working Group, Kampala, 2009, 1.

${ }^{28}$ MiNISTRY OF EDUCATION AND SPORTS, The Education and Sports Sector Annual Performance Reports (ESSAPR) 2008. Kampala, Uganda, 2009. http://www.education.go.ug/ESAPR.htm [accessed 22 June 2009].

${ }^{29}$ MINISTRY OF EDUCATION AND SPORTS, The Northern Uganda Education Assessment, Kampala, Uganda, 2006.

www.education.go.ug/Final\%20Needs\%20Assessment\%20Report.doc [accessed 18 July 2009].
} 
Book Chapter in Derluyn, II, Mels, C., Parmentier W., and Vandenhole W. (eds.) (2012) Re-Member: rehabilitation, reintegration and reconciliation for war-affected children, volume 11 Series on Transitional Justice. Cambridge/Antwerp/Portland: Intersentia Publishers.

Youth are often affected by early drop-out before completion of their Primary Leaving Exams (due to financial constraints, early pregnancy, death of the parents/guardians, and/or abduction, among others, see table 1 below), ${ }^{30}$ or, after completion of primary school, do not have the means to continue with their education at secondary school level. During the displacement, the most pressing needs of the population were mainly identified by NGOs and donors in order to determine the required funding and support. The focus of the interventions was usually emergency relief rather than development cooperation. Areas such as post-primary and non-formal education were not among the priorities.

From the onset of the movement from IDP camps into transit sites and return areas, the population highlighted the need to re-establish basic services such as schools as the most pressing need in the return process. ${ }^{31}$ Lack of such services outside the IDP Camps decreased the chance of many youth to access secondary education, and instead increased protection concerns in relation to children and youth: many children opted to remain in the camps in order to attend classes, while their parents were occupied with work in the gardens and re-establishing their new homes elsewhere. Although some of these children were left on their own in the IDP camps without the supervision and care of older family members, many were taken care of by elder siblings, often youth.

\begin{tabular}{|l|c|c|}
\hline Reasons & Number & \% \\
\hline Financial constraints & 79 & 54.9 \\
\hline Pregnancy & 21 & 14.6 \\
\hline Death of parent(s) & 12 & 8.3 \\
\hline Abduction & 8 & 5.6 \\
\hline Lack of family support & 6 & 4.2 \\
\hline Responsibilities at home & 5 & 3.5 \\
\hline Never attended school & 2 & 1.4 \\
\hline Dropped out due to displacement & 1 & 0.7 \\
\hline Insecurity & 1 & 0.7 \\
\hline Sickness & 1 & 0.7 \\
\hline Sickness/disability of the parents & 1 & 0.7 \\
\hline Other & 7 & 4.9 \\
\hline
\end{tabular}

Table 1: Reasons for dropping out of school: results of an assessment among 144 youth beneficiaries of an AVSI project in Kitgum District

Since the beginning of the return process, a shift from emergency relief in the education sector, through which mainly temporary structures and materials were put up for children in the IDP camps, to development projects in the areas of return focused on quality, and age-appropriate education has started. The provision of educational services, participation in psychosocial programmes, vocational training and support through income generating activities can support the successful reintegration of former abductees and provide essential support to other war-affected youth, by helping to restore hope for the future with opportunity. ${ }^{32}$

As for the returnees, once out of captivity many suggest a reintegration agenda sensitive to their economic wellbeing and social relations in the context of their culture and tradition, proposing psychosocial activities, vocational and entrepreneurial skills training, provision of credit facilities, and an education system that recognises their background and needs. $^{33}$

Vocational training is "at the crossroads of economic recovery, education and rehabilitation and reintegration, and can be a key component of development, a method for upgrading the labour force and a factor in the holistic development of youth", ${ }^{34}$ therefore one of the educational methods that can provide skills for livelihoods and employment. However,

\footnotetext{
${ }^{30}$ The statistics refer to the evaluation of a project of AVSI that was implemented under the Northern Uganda Rehabilitation Programme (NUREP), and are part of AVSI's final report to NUREP.

${ }^{31}$ UNDP, Returning to uncertainty? Addressing vulnerabilities in northern Uganda, Kampala, Uganda, 2007.

www.fafo.no/nyhet/return2uncertanity.pdf [accessed 22 June 2009].

${ }^{32}$ A. VEAL and A. STAVROU, Violence, Reconciliation and Identity: The Reintegration of Lord's Resistance Army Child Abductees in Northern Uganda, Monograph No 92, Institute for Security Studies, Pretoria, 2003. http://www.iss.co.za/pubs/Monographs/No92/Chap3.html [accessed 17 August 2009]; J. Annan, C. Blattman and R. Horton, The State of Youth and Youth Protection in Northern Uganda: Findings from the Survey of War Affected Youth. Kampala, UNICEF Uganda, 2006.; WoMEN's COMMISSION FOR REFUGEE WOMEN AND CHILDREN, Youth and Sustainable Livelihoods: Linking Vocational Training Programs to Market Opportunities in Northern Uganda, Colombia University, 2008.

www.womenscommission.org/pdf/ug ysl_rep.pdf [accessed 5 July 2009]; J. ANNAN, C. BLATTMAN, K. CARLSON and D. MAZURANA, The State of Female Youth and in Northern Uganda: Findings from the Survey of War Affected Youth, Phase II. Kampala, UNICEF Uganda, 2008.

${ }^{33}$ K.A. P'OLAK, 'Coping with Life in Rebel Captivity and the Challenge of Reintegrating Formerly Abducted Boys in Northern Uganda', (2007) 20 Journal of Refugee Studies 4, at 641-661. http://jrs.oxfordjournals.org/cgi/content/abstract/20/4/641 [accessed 13 August 2009].

${ }^{34}$ WOMEN's COMMISSION FOR REFUGEE WOMEN AND CHILDREN, Youth and Sustainable Livelihoods: Linking Vocational Training Programs to Market Opportunities in Northern Uganda, Colombia University, 2008, 1. www.womenscommission.org/pdf/ug_ysl_rep.pdf [accessed 5 July 2009].
} 
Book Chapter in Derluyn, II, Mels, C., Parmentier W., and Vandenhole W. (eds.) (2012) Re-Member: rehabilitation, reintegration and reconciliation for war-affected children, volume 11 Series on Transitional Justice. Cambridge/Antwerp/Portland: Intersentia Publishers.

there is a need to diversify the skills for training, as over the years large numbers of tailors, masons and carpenters have been produced who encounter challenges in finding employment or self-employment opportunities. ${ }^{35}$

Access to education and support for improved livelihoods for many war-affected youth in northern Uganda cannot be the only means of empowering them to overcome their challenges; but they can be supported to gain self-confidence and to redefine their roles as independent and important members of their communities. ${ }^{36}$ The following paragraphs outline the experiences of AVSI in supporting vulnerable youth through education and gaining a livelihood.

\subsection{AVSI's programming}

AVSI, an international non-governmental organisation (NGO), was founded in 1972 in Italy. In Uganda, AVSI started implementing projects in northern Uganda in 1984. Throughout the conflict in northern Uganda, AVSI has implemented projects in the sectors of education, health, HIV/AIDS, disability, food security and livelihoods, protection, and water and sanitation. Over the years, AVSI's programmes have always been a mixture of emergency relief and developmental projects, aiming to provide immediate relief for persons in the IDP camps combined with structural support to the existing health and education systems such as hospitals, health centres and (displaced) schools.

Following the above outlined recommendations and experience in emergency relief and development cooperation in northern Uganda, AVSI developed a holistic approach to respond to the needs of the returning children and youth. AVSI's psychosocial and education programmes for war-affected children and youth, which started in 1998, have benefited over 60,000 children and youth to date. ${ }^{37}$ The support to returning children, youth and their communities ranges from cooperation with district authorities, economic support, for example through income generating activities, community dialogue, rehabilitation and construction of school facilities, provision of teaching and learning aids and other materials, training of teachers and school administrators to improve the quality of teaching and management of school affairs, services aimed at health and HIV/AIDS, water and sanitation interventions, support to children and youth with special needs, and support to formal and non-formal vocational training, including provision of start-up tools and sponsorship for individual students, business skills training and industrial training for students, as well as psychosocial support programmes which include individual and group counselling, and follow-up of those who participated in counselling sessions. In all these activities educating the youth, starting from their potential, is central to the package provided.

For AVSI, education is not limited to accessing the educational system and acquiring a diploma, but is seen as an overall good to realise ones' potential through experience, not only in the classroom but also in society in various settings and in various roles. To achieve this, educational activities are not only focused on quantity such as the provision of materials, school structures and numbers of teachers, but also on quality, including teacher training, in class- and community-based follow-up and comprehensive packages for vulnerable children and youth and their families, including not only fees but also health care, psychosocial counselling and livelihood activities. All project activities are implemented in close collaboration with the youth, local partner organisations and schools, and local leaders.

\subsubsection{Identification of beneficiaries}

The beneficiaries of AVSI's support for education are among the most vulnerable children and youth who would otherwise fall through the educational "system", and livelihood activities target youth who are not enrolled in formal or non-formal programmes.

Vulnerability for AVSI is a combination of factors that cannot be reduced to categories (i.e. people living with HIV/AIDS, formerly abducted children/youth, people with disabilities, child mothers etc.) but instead are determined by the living situation of each individual. The selection of beneficiaries is therefore based on an assessment of the overall wellbeing of the person based on indicators of health, economic and psychosocial wellbeing.

The children and youth are usually referred by local authorities and leaders from the community. After receiving referrals, AVSI conducts assessments in partnership with local leaders. The assessments are done at the home of each potential beneficiary, and family and other community members are interviewed as well. This door-to-door approach greatly contributes to a thorough verification of whether a person who has been referred by local leaders is really vulnerable or not.

\footnotetext{
${ }^{35}$ Northern Uganda Youth Development Centre , Consultative Mission Report: Synopsis/Executive Summary, Kampala, 2006. http://www.thecommonwealth.org/Shared_ASP_Files/UploadedFiles/2CB1DFF2-ACEA-454E-9E5C-

5A54CC1E2BE6 ConsultativeMissionReport4-10Oct06NorthernUgandaYouthDevelopmentCentre.pdf [accessed 19 June 2009]; WoMEN's COMMISSION FOR REFUGEE WOMEN AND CHILDREN, Youth and Sustainable Livelihoods: Linking Vocational Training Programs to Market Opportunities in Northern Uganda, Colombia University, 2008. www.womenscommission.org/pdf/ug_ysl_rep.pdf [accessed 5 July 2009].

${ }^{36}$ F. BANNINK-MBAZZI, A. LORSCHIEDTER, A.H. AMONY and F. OPOK, Persons living with physical disabilities in the return process in Northern Uganda, (2009) 20 Journal for Disability and International Development .2, at 4-9.

${ }^{37}$ AVSI, The Psychosocial Support Program of AVSI in Uganda, a case study 1999 - 2005. AVSI Uganda, Kampala, 2005.
} 
Book Chapter in Derluyn, II, Mels, C., Parmentier W., and Vandenhole W. (eds.) (2012) Re-Member: rehabilitation, reintegration and reconciliation for war-affected children, volume 11 Series on Transitional Justice. Cambridge/Antwerp/Portland: Intersentia Publishers.

The assessment includes data collection of personal and household information, education, livelihood, health and motivation. It does not focus only on challenges and deficits, but rather evaluates the available resources and opportunities, looking at both strengths and weaknesses.

\subsubsection{Supporting pre-primary, primary and secondary education}

AVSI's education programs endeavours to improve the capacity of local communities and families to provide sustainable and high quality care for the identified vulnerable children and youth. In 2008, 3,000 children were supported in pre-primary institutions in northern Uganda. AVSI supports early childhood development centres (preprimary) through the provision of school materials, playground equipment, training of early childhood development caregivers, and community sensitisations.

On an annual basis, over 7,500 vulnerable children and youth received scholarships for primary and secondary education, including school fees, school materials, health care, psychosocial support and livelihood activities based on the individual needs of each child and his/her family and community. Targeted interventions to improve school structures, such as rehabilitation work and the provision of teaching materials, as well as water and sanitation facilities, are also provided to schools in AVSI's area of operation.

A cross-cutting theme in AVSI's work including the education sector is disability. ${ }^{38}$ Alongside the medical rehabilitation support to children and youth with special needs, AVSI supports annexes for blind children in primary schools and a primary school for the deaf in northern Uganda with special needs materials, training of staff, student sponsorships, and community sensitisation to improve access and quality education for children with visual and hearing impairment. AVSI also aims to improve access for children and youth with other disabilities by creating ramps and installing disabled-friendly latrines and other devices in schools.

\subsubsection{Supporting vocational training}

After assessment, a selection of the most vulnerable and motivated youth is made by a team including AVSI staff and local leaders. It is followed by a discussion with the youth and his/her family members, and with local leaders, clarifying the modalities of the support for vocational training.

Support to vocational training is always combined with a short period of industrial training and training in business skills. Depending on the most urgent needs, the schools where the youth follow their courses receive support such as tools for instruction, textbooks and furniture. In case of rehabilitation works needed at the schools, construction activities are carried out by the students during their practical lessons. Instructors are invited to undertake training in quality education, psychosocial support, HIV/AIDS awareness, and the code of conduct. Early in 2008, counsellors were sent for initial assessment to the schools to assess psychosocial needs of youths and teachers within the schools. In 2008, 184 students were supported in five different (mainly non-formal) training courses (47 percent females and 53 percent males). The average age of the students was 19.4 years, and their households comprised 4 persons on average. Half of the students completed primary education (51 percent), while 22 percent attended at least one year of secondary school. Over 60 percent had lost both parents, 12 percent had been abducted by the LRA, 9.8 percent headed a household, 9.8 percent were young mothers, 14.1 percent of the youth were handicapped, while other vulnerabilities included youth at risk of abuse and staying with elderly or sick guardians.

Psychosocial counselling was offered to all students in the vocational training schools, aimed at enhancing the coping mechanisms of the youth and focusing on interventions that could assist the students in addressing their problems on the individual as well as on the school and community levels. Students with severe psychiatric symptoms, including hallucinations and suicidal tendencies, were referred to a health centre or hospital with psychiatric staff and medical supplies.

Follow-up of youth who have completed vocational training in Kitgum shows that the majority of the youth have an increased household income after their training, applying knowledge gained through business skills training even if they do not work in the field of their vocational training. Also, many of the youth are reporting an improved psychosocial wellbeing due to the important role they are playing after the training as providers and helpers in their families and communities.

\subsubsection{Training for teachers and other school stakeholders, and community sensitisation}

Annually AVSI trains about 2,000 teachers in quality education, life skills to prevent HIV/AIDS, and psychosocial support in various schools throughout Uganda using training modules developed by field practitioners. ${ }^{39}$ The quality

\footnotetext{
${ }^{38}$ F. BANNINK-MBAZZI, A. LORSCHIEDTER, A.H. AMONY and F. OPOK, Persons living with physical disabilities in the return process in Northern Uganda, (2009) 20 Journal for Disability and International Development .2, at 4-9.

${ }^{39}$ AVSI's Training Manuals on Quality Education titled "Basic Training on the Risk of Education", on life skills titled "The Value of Life", and on psychosocial support titled "Handbook for Teachers" and "Training Manual for teachers" can be downloaded from http://www.avsi.org under "pubblicazioni".
} 
Book Chapter in Derluyn, II, Mels, C., Parmentier W., and Vandenhole W. (eds.) (2012) Re-Member: rehabilitation, reintegration and reconciliation for war-affected children, volume 11 Series on Transitional Justice. Cambridge/Antwerp/Portland: Intersentia Publishers.

education training reflects on the meaning of education in order to appreciate the fact that education should form persons able to deal with all the challenges of life, developing their potential, values and attitudes and taking up their commitments and responsibilities. Through a positive educational approach the person is encouraged to understand different dynamics and factors in the educational process and promote growth. The training requires constructive and active participation, focusing on a critical reflection on their professional and personal experience.

The life skills training concentrates on basic behavioural change in the context of HIV/AIDS prevention. Respect for one's life, and therefore for one's body and health, are promoted and behavioural change processes are addressed. The training module incorporates information about HIV/AIDS transmission, but also emphasises the needs of a person and the meaning of love, freedom and sex.

The psychosocial support training covers topics such as the developmental growth of youth, trauma, the recovery process, and listening and basic counselling skills. ${ }^{40}$ The training is not aimed at training teachers and instructors to become counsellors, but to develop their skills to identify and refer children and youth with psychosocial problems. The teachers and instructors are encouraged to practise the acquired skills in class, and also involve the family and community of the students in the education and support. The trained instructors support the counselling activities through assisting the counsellors in identifying the general problems of the students, but also refer students who might benefit from individual counselling.

An evaluation of the training of teachers in psychosocial support showed that teachers and instructors who have undergone the training feel empowered to better understand the individual problems of students and feel able to respond appropriately in difficult situations with students in the school but also outside. Many of the teachers and instructors felt the training also improved their understanding of the general developmental growth of youth, something they were never trained in as many of the instructors are not formally trained teachers but craftsmen who instruct in a certain vocation.

A male teacher who participated in one of the training courses said afterwards:

Before the training, I used to be a very strict teacher. I would use sticks time and again for whatever mistake the students would make. I realized that the students would run away whenever they saw me around, and I was wondering why they were doing this. After the training, I stopped using sticks. Today, the students like me. They are very interested in my lessons, and they admire my teaching. I have learnt to be more tolerant with the students when they don't perform up to my expectation, and I always try to understand why a particular student is not performing well, and which are the underlying problems that prevent him or her from doing well in class. I take time talking to them about their problems. This has made my relationship to the students much more positive.

AVSI also offered training for Boards of Governors (BoG) and Parent-Teacher Association (PTA) members in 26 secondary and vocational schools in order to improve the management of the schools' affairs and to clarify the different roles of the two bodies. Training was therefore organised for $122 \mathrm{BoG}$ members on policy issues and management skills and 34 PTA members were trained in their roles and responsibilities.

In 2009, AVSI organised community sensitisations on the value and importance of education in all sub-counties where partner schools were located. During quarterly coordination meetings that were held at sub-county level to share information with local leaders and partners on the implementation of the activities, which were also meant to obtain inputs for activities that were still to be carried out, AVSI was requested to sensitise parents on the value and importance of education, and to go on to parish level in order to reach as many community members as possible. Subsequently, 50 parishes were covered and the sensitisations were attended by a total of 6,687 community members. In order to increase the coverage of the sensitisations and to go in depth into issues concerning the importance and value of education, 35 radio talk shows were organised, facilitated by district and local leaders, teachers and students of the partner schools.

\subsubsection{Supporting livelihoods}

From 2007 to 2009, AVSI provided income generating activities (IGA) addressing vulnerable youth in Kitgum District. 24 groups of youth with a total of 554 members have been supported in eight sub-counties in Kitgum District, in addition to 286 vocational students who completed their studies in four vocational schools.

The results of this intervention show that IGA can contribute towards improving the economic wellbeing of the beneficiaries in terms of assets owned and the types of economic activity they are involved in. Engaging in IGA can also help vulnerable persons in becoming productive and active members of society, and can improve social consideration and family support. Improvements can as well be registered in the overall health situation and in school attendance.

\footnotetext{
${ }^{40}$ AVSI's Training Manual for Teachers and the Handbook for Teachers were included in the technical kit of the Interagency Network for Education in Emergencies (INEE) and also published on the network's website: http://www.ineesite.org. The manual is currently under revision to respond to the changed needs in northern Uganda, focusing on return and resettlement.
} 
Book Chapter in Derluyn, II, Mels, C., Parmentier W., and Vandenhole W. (eds.) (2012) Re-Member: rehabilitation, reintegration and reconciliation for war-affected children, volume 11 Series on Transitional Justice. Cambridge/Antwerp/Portland: Intersentia Publishers.

According to their self-evaluation, the beneficiaries appreciated the psychosocial effects of IGA more than the economic effects; this could also be a consequence of the fact that the economic wellbeing of the beneficiaries is hindered by the increasing number of dependants as the income capacity of the person rises.

The objectives of AVSI's IGA interventions are to improve the quality of life of the most disadvantaged people, to enable beneficiaries to increase their household income from a sustainable livelihood, to create self-employment through engagement in productive activities, and to increase resilience among the most vulnerable people.

\subsubsection{Group dynamics training}

After assessment and identification of the beneficiaries of the IGA support, the youth underwent training in group dynamics since group cohesion and peer support are the prerequisites for a well-functioning group structure. This training aims at strengthening the structure and internal dynamics of the either already existing group or of the group-tobe, and at building positive dynamics and structures, especially in the newly created groups. The training in group dynamics also focuses on basic skills in the leadership and management of a group, communication habits, and mechanisms of decision making.

\subsubsection{Business skills training}

Through learning the basics of business planning and business notions it is possible to handle any kind of business with a low requirement in technical skills. After the group dynamics training, the group members and vocational students attending the last year of their vocational studies and on the verge of entering the job market have been trained on how to identify, select, plan and start a feasible and viable IGA. The aims of this training were to raise awareness about possible sources of start-up capital, to enable existing entrepreneurs to identify problems and constraints that affect the growth and development of their IGAs, to devise a way forward to address the problems, and to deepen the participants' understanding of the value of saving, of how to save and where to save.

One of the main challenges faced by graduates from the vocational training courses is the transition from school to work. The business skills training equips the youth with additional skills such as customer care, saving and business management that help them to create and maintain a business and that are necessary for them to overcome the transitional challenge from school into the labour market. During the training, information on the importance of saving, the use of savings and the use of saving and credit facilities was provided (referral to the existing facilities, information on informal saving and credit systems such as revolving loans, village saving and loan associations). The training in business skills is particularly important in meeting Ministry of Education and Sports directives to introduce entrepreneurial skills training into the curriculum of vocational skills.

The follow-up indicates that almost all youth who attended the training are practising gainful economic activities, and that they have added advantages over the youth that did not undergo the training in business skills to supplement their vocation. Most of them are involved in small-scale businesses ranging from baking, carpentry workshops, nursery bed management (selling of seedlings) to construction. Their monthly income ranges from 150 EUR to 200 EUR, depending on the location and the types of industry in which they were trained. The follow-up also indicates that many of the graduates of catering courses have been able to get gainful employment within the nearby town council.

\subsubsection{Improved psychosocial wellbeing}

The IGAs contribute to improving the economic wellbeing of the beneficiaries in terms of assets owned and the types of economic activity they are involved in. Engaging in income generating activities can help vulnerable youth in becoming productive and active members of society, improving social consideration and family support. Improvements are also registered in the overall health situation and in school attendance.

The area that registers improvement both according to the increase of specific indicators and in the perception of the beneficiaries is the psychosocial situation. The percentage of vulnerable youth feeling that the family is very caring almost doubles and the percentage of those that do not feel care reduces from 30 to 10 percent (Graph 1). According to the leader of a youth group, members are now able to pay for the school fees of their children and for medical treatment. 
Book Chapter in Derluyn, II, Mels, C., Parmentier W., and Vandenhole W. (eds.) (2012) Re-Member: rehabilitation, reintegration and reconciliation for war-affected children, volume 11 Series on Transitional Justice. Cambridge/Antwerp/Portland: Intersentia Publishers.

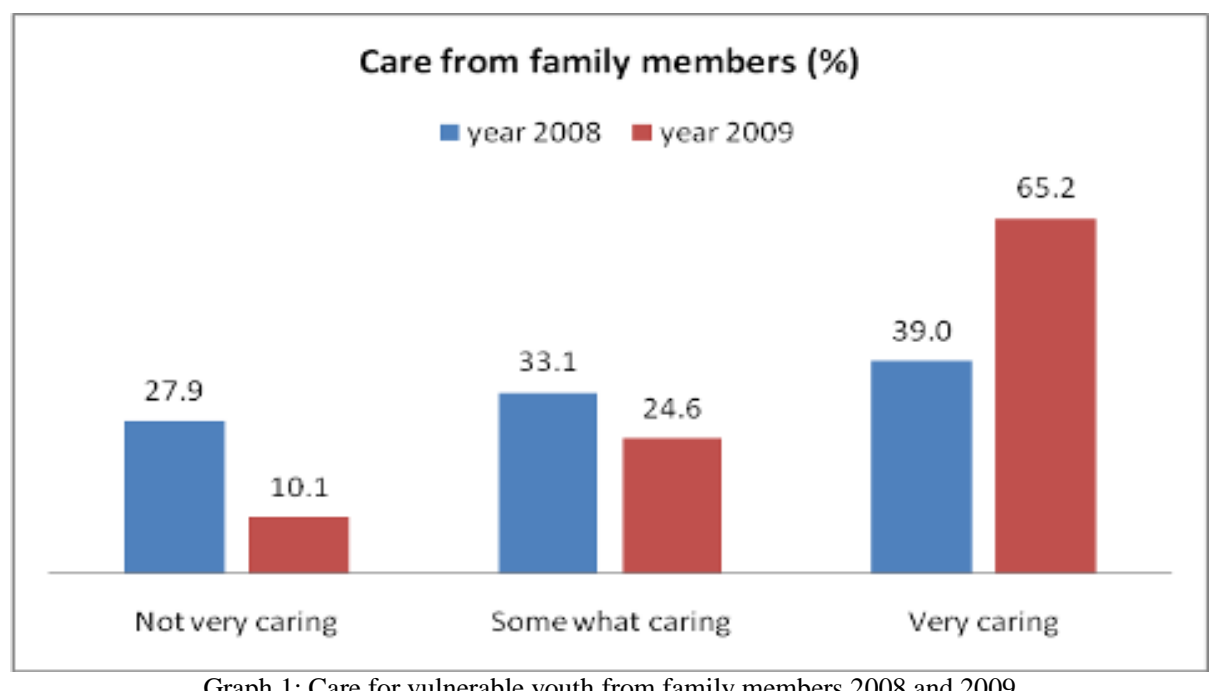

Graph 1: Care for vulnerable youth from family members 2008 and 2009

Also the perception of community support changes dramatically. The percentage of cases where community members said things to insult or hurt the beneficiary or his/her children in the previous year dropped from 33 to 12 percent, the percentage of cases where community members have been physically aggressive towards the beneficiary or his/her children dropped from 11 to 6 percent and that of community members not allowing their children to play with those of the beneficiaries has halved.

At the same time, the overall perception of the psychosocial situation and overall sense of belonging to the community increased considerably.

\subsubsection{Group businesses leading to micro-enterprises opportunities}

After the training courses, groups and the vocational students have been helped in business selection according to the viability of the business, market demand and group capacity. Start-up capital ranging from 200 to 500 EUR, depending on the business proposed, were delivered to each group. With the support and the constant follow-up and advice provided by AVSI staff and local leaders, all the groups have been able to start profitable business activities.

Amongst the micro-enterprises started up have been the retail selling of agricultural and non-agricultural products, food processing, petty business, a depot for selling sodas, and agricultural production.

Spontaneously, most of the groups have concurrently started a saving scheme whereby members can borrow from the group to start individual businesses or meet the household's basic needs. For instance, most of the members from two sub-counties are involved in petty business such as selling cassava, small fish and making small cakes, and are gaining profits both from the group and from the individual IGA.

Some of the groups have used the profits gained from one business to start other activities, showing good riskdifferentiation capacity: one group is concurrently running a grinding mill business and selling crops.

Most of the vocational students (229 total: 142 male, 87 female) have instead been provided with start-up kits to enable them to employ the skills learned in the courses attended and enter the job market directly as service providers. A female beneficiary of IGA support to youth groups said:

In our group, we have love for the others, and we are giving moral support to each other. For example, sometimes I am selling on behalf of other group members who may be having problems. The training on business skills has helped me to developed qualities that I did not have before, such as courage to face customers, people I have never met before. Our business in the group is going on very well, and our capital has already increased. Even on household level, my life has improved a lot. I am now eating twice a day instead of only having one meal, and I manage to save money which allows me to buy things which I couldn't afford to buy before. I can now even help my family members when they are having problems. Other community members who used to look down at me are now showing me respect. My life has really changed and I am sure I will not be the same hopeless person like before.

\section{Conclusion}

Returnees from the LRA have usually been classified into categories, e.g. depending on the length of life in captivity and experiences had during the time in the "bush". This categorisation can facilitate programming that tends to leave out many other vulnerable people who may have a similar or even greater need to be supported. 
Book Chapter in Derluyn, II, Mels, C., Parmentier W., and Vandenhole W. (eds.) (2012) Re-Member: rehabilitation, reintegration and reconciliation for war-affected children, volume 11 Series on Transitional Justice. Cambridge/Antwerp/Portland: Intersentia Publishers.

Acknowledging that although many former LRA abductees have suffered a wide range of abuses during their time in captivity, the war in northern Uganda has affected many if not most children and youth in the region through displacement, loss of family members, witnessing horrific events, and a lack of access to basic services such as health and education, ${ }^{41}$ the emphasis on child soldiers - moreover, with a focus on children only - can seem disproportionate to the effort required for restoring "normal life" in Uganda. Research on reintegration usually concludes that humanitarian services at all levels should strengthen the capacity of families to care for the psychosocial, educational and material needs of returnees at all levels. ${ }^{42}$ More specifically, practitioners are called upon to develop programmes not just for former "child soldiers", but rather for all vulnerable children and youth, with support for building livelihoods by focusing on alternative age-appropriate and accelerated education and economic development, taking into consideration individual differences. The importance of economic recovery has been highlighted in several studies, which recommend that aid agencies should be complementing internal motivation by supporting an environment conducive to recovery and rehabilitation rather than providing humanitarian support that may weaken internal structures and worsen vulnerabilities. ${ }^{43}$

The holistic approach of AVSI described in this article is based on each person's needs, abilities and strengths, with a broad focus on war-affected children and youth in northern Uganda, combining educational, psychosocial and livelihood activities.

\section{List of abbreviations}

$\begin{array}{ll}\text { AVSI } & \text { AVSI Foundation, formerly called Associazione Volontari per il Servizio Internazionale } \\ \text { BoG } & \text { Board of Governors } \\ \text { DDR } & \text { Demobilisation, Disarmament and Reintegration } \\ \text { HIV/AIDS } & \text { Human Immunodeficiency Virus/Acquired Immune Deficiency Syndrome } \\ \text { ICC } & \text { International Criminal Court } \\ \text { IDP } & \text { Internally Displaced People } \\ \text { IGA } & \text { Income Generating Activities } \\ \text { LRA } & \text { Lord's Resistance Army } \\ \text { NGO } & \text { Non-Governmental Organisation } \\ \text { NRA } & \text { National Resistance Army } \\ \text { PTA } & \text { Parent-Teacher Association } \\ \text { PTSD } & \text { Post-Traumatic Stress Disorder } \\ \text { UN } & \text { United Nations } \\ \text { UNDP } & \text { United Nations Development Programme } \\ \text { UNOCHA } & \text { United Nations Office for the Coordination of Humanitarian Affairs } \\ \text { UPDF } & \text { Ugandan People's Defence Forces }\end{array}$

\footnotetext{
${ }^{41}$ C. DoLAn, Which children count? The politics of children's rights in northern Uganda. Conciliation Resources, London, 2002. http://www.c-r.org/our-work/accord/northern-uganda/which-children-count.php [accessed 11 August 2009]; M. BOAS and A. HATLOY, The Northern Uganda IDP Profiling Study, Department of Disaster Preparedness and Refugees of the Office of the Prime Minister and United Nations Development Programme, Kampala, 2005, Vol. 1.; P.N. Pham, P. VincK, M. Wierda, E. Stover and A. DiGiovanni, Forgotten Voices: A Population-Based Study of Attitudes about Peace and Justice in Northern Uganda, International Centre for Transitional Justice and Human Rights Center, University of California, Berkeley, 2005. http://repositories.cdlib.org/hrc/reports/2005 07Forgotten-Voices [accessed 8 July 2009 ].

${ }^{42}$ L. Castelli, E. LocatellI and M. CANavera, Psycho-Social Support for War-Affected Children in Northern Uganda: Lessons Learnt. Coalition to Stop the Use of Child Soldiers, London, 2005, 5. www.child-soldiers.org/resources/psychosocial [accessed 10 July 2009]; J.N. CoRBIN, 'Returning home: Resettlement experiences of formerly abducted children in northern Uganda', (2008) Disasters (Online Early Articles), 316.

${ }^{43}$ R. LOCKE, 'Community-driven economic development in Northern Uganda', (2006) 36, Humanitarian Exchange Magazine.

http://www.odihpn.org/report.asp?id=2859 [accessed 10 July 2009] [accessed 17 August 2009]; USAID, Field Report No. 2 - Economic

Strengthening for Vulnerable Children: Principles of Program Design and Technical Recommendations for Effective Field Interventions, 2008. www.aed.org/.../Principles-of-Program-Design-Economic-Strengthening-for-Vulnerable-Children-Youth.pdf [accessed 28 July 2009]; THE SEEP NETWORK, Minimum Standards for Economic Recovery after Crisis, Washington, 2009.

http://communities.seepnetwork.org/sites/hamed/files/Econ_Recovery_Standards.pdf [accessed 17 July 2009].
} 